\title{
Is Abbot cast still relevant today? Preliminary randomized study based on 3D analysis
}

\author{
J Deceuninck $^{1 *}$, JC Bernard ${ }^{1}$, C Lecante $^{2}$, E Berthonnaud $^{1}$, S Verlet $^{1}$ \\ From 8th International Conference on Conservative Management of Spinal Deformities and SOSORT 2011 \\ Annual Meeting \\ Barcelona, Spain. 19-21 May 2011
}

\section{Background}

In 1913, it's the first time we talk about Pr. Abbott for the correction of "old scoliosis". Instructions for Abbott cast are:

- Stiff scoliosis with moderate to significant Cobb angle

- No cardio-pulmonary contraindication

- No cervico-occipital disorder

- No vessel fragility

But is Abbott cast still relevant today? And if it's right, is it in the same conditions?

\section{Materials and methods}

This is a preliminary randomized study lead at the CMCR des Massues in Lyon since April 2010 to January 2011 about 40 teenagers treated by Abbott cast. First group $(n=17)$ have had 3D analysis before cast and second $(n=23)$ group after cast. With the $3 \mathrm{D}$ analysis we have worked out if the thoracic band was put by classical method or was conversely put (based on plane of maximum curvature (PMC) parameters). We have analyzed Cobb angles in frontal and sagittal plane and PMC parameters.

\section{Results}

There was no more cervical lordosis in $21,7 \%$ in the second group (3D analysis after cast) and 5,8\% in first group. There was an improvement of lumbar lordosis $\left(10,67^{\circ}\right)$ in first group with a normalization of the number of vertebra in this one. There was lesser decrease of kyphosis in the first group but this result was not significant.

${ }^{1}$ Croix Rouge française-CMCR des Massues Lyon, France

Full list of author information is available at the end of the article

\section{Conclusions}

Abbott cast is still relevant today but not with the same practical details. We have to introduce 3D analysis in our daily practice.

\section{Author details \\ ${ }^{1}$ Croix Rouge française-CMCR des Massues Lyon, France. ${ }^{2}$ Ets Lecante, Lyon, France.}

Published: 27 January 2012

doi:10.1186/1748-7161-7-S1-040

Cite this article as: Deceuninck et al: Is Abbot cast still relevant today?

Preliminary randomized study based on 3D analysis. Scoliosis 2012 7(Suppl 1):O40
Submit your next manuscript to BioMed Central and take full advantage of:

- Convenient online submission

- Thorough peer review

- No space constraints or color figure charges

- Immediate publication on acceptance

- Inclusion in PubMed, CAS, Scopus and Google Scholar

- Research which is freely available for redistribution 